\author{
Tanja Radošević ${ }^{1}$ \\ Marija Runić Ristić
}

\section{QUALITY OF WORK LIFE SHOWN IN CORRELATIONS BETWEEN EMPLOYEES WORK MOTIVATION AND INDICATORS OF EXTERNAL COMMUNICATION OF AN ORGANIZATION}

\begin{abstract}
This paper is aimed to show the quality of work life seen through correlation among attitudes about workplace quality and quality of organizational communication with indicators of external communication of the organization. It questions the employees in public, state and private sector in Serbia and 9 other countries of Southern and Western Europe. This work intends to prove that the quality of work life, and employees' motivation, as seen through attitudes of the employees, strongly correlates with indicators of external communication of the organization. The findings show that there is both positive and negative correlation between (un)successful external communication of the organization and motivation of its employees that describe Quality of work life of employees. This paperwork presents contribution to the current sources explaining the Quality of life among employees and its link to external communication of the organization.
\end{abstract}

Keywords: quality of work life, employees, external communication of the organization, work motivation of the employees, employees' attitudes

\section{Introduction}

Sinha (2012) argues that questioning employees on their opinion on Quality of their Work Life and job satisfaction is of great importance for the company they work for, and that it helps employers to determine what improvements can be made. From the organization's point of view, the most important elements are motivation of the employee, the influence of the work (amount and specifics) on the employee, participation of the employee in solving problems that occur in the company and their decisionmaking abilities. There is a broadly accepted concept defined by The WHOQOL Group
(1998): "Quality of life has been defined as people's perception of their position in life in the context of the culture and value systems in which they live, and in relation to their goals, expectations, standards and concerns." Robert et al (2009) as well Schuessler \& Fisher (1985) consider that Quality of Life is highly dependent on person's socioeconomic status. The authors also claim that Quality of life is a mere function of someone's psychological state, physical health, relationship to their social and physical environment and all other social relationships. Quality of Work life depends on all these factors, where the environment is someone's working place. Subdimensions or facets of these dimensions are numerous:

\footnotetext{
${ }^{1}$ Corresponding author: Marija Runić Ristić

Email: runic@famns.edu.rs
} 
activities conducted on daily level, working capacity, dependence on medical aids, selfconfidence, personal relationships and their functionality, physical appearance, social care system and an individual's access to it, job vacancy access, financial resources, opportunities for Life Long Learning and gaining new skills and competences, especially in their working environment, which is supposed to be stimulating enough. Swamy et al. (2015) argue that Quality of Work Life presents an extent to which an employee is satisfied with his or her working needs and personal achievement, while being in the workplace and doing actions towards achieving goals of their organization. These authors also mention that the Quality of Work Life can be enhanced greatly by flexible hours offered to employees, the possibility to widen autonomy at work for every employee, job enrichment etc., which will all lead to greater job satisfaction and improved perception of their Quality of Work Life, as well as provide numerous advantages for both employees and the organization. Similar claims come from the research taken by Harrington \& Hall (2007) - where they point out that fewer working hours can have numerous forms, but nevertheless give employees greater control over their work and mere process of the work and its direction. That way, employees get more balance between work life and private life, thus resulting in considerably higher degree of Quality of Work Life. Lau et al. (2001) point out that working environment should be supportive and favourable, in order for employees to feel recognized and supported in terms of their job security, promotions, rewards, bonuses and opportunities to grow and be promoted within the organization they work in. Hosseini et al. (2010) came to an interesting conclusion in their study; namely, achieving Quality of Work Life or the quality of its system is one of the most interesting ways to achieve job enrichment. According to their study, career balance, career satisfaction and career achievement are variables that will most probably lead to good Quality of Work Life. This study also points out that Quality of Work life is closely related to employees' higher performance if there are continuous rewards, promotions, as well as opportunities to grow and improve their skills. The opportunity to grow and be recognized and promoted is also in the spotlight of the research conducted by Sharma \& Verma (2013). They have identified seven variables that help establish and measure Quality of Work life. These are: fair compensation, employees' motivation, opportunities for growth, pleasant and stimulating working environment, communication flow, job satisfaction and motivation of employees. Mohan \& Kanta (2013) examined the most prominent variables that as accurately as possible define Quality of Work Life in organizations. They included inter-personal relations within the company, working conditions, autonomy of the work place, trust among workers, training, decision making, possibilities to advance in career, management of conflict, support by the authorities, recognition by them, rewarding system etc. Their results revealed that there are several key factors defining Quality of Work Life: dynamics of the group, working environment, organizational climate, personal growth and advancement as well as motivation. Sahni (2017) explains that the Quality of work life mainly refers to the quality of mutual connection of employees and the environment they work in, thus emphasizing economic satisfaction, technical conditions at working place, as well as human dimensions and relationships among employees and their relationship to the organization management. Mejbel et al. (2013) reveal results of their study, which are quite similar to Mohan \& Kanta (2013). Namely, they mention the most prominent drivers for Quality of Work Life such as benefits, compensation, rewards, safety and security of the job, career development and, respectively, communication. Drivers that 


\section{Intermationall Qualilty Conference 13}

$\mathrm{R} U \mathbf{A} \| \mathbf{I} \boldsymbol{Y}$

were not the most frequent ones, but yet, still triggering, according to this study, were involvement of the top management, cohesion and balance between work life and private life, as well as job satisfaction and motivation of the employee, which is one of the main focuses of this paper.

Motivation always comes from within and must be an inner human need. For this very reason, it is not something that can institutionalize or otherwise be externally imposed. There are two reliable ways to motivate people to change. The first strategy involves constant pointing out to an unfavourable existing situation, creating such dissatisfaction that should motivate change and make the need for it, while the other strategy is constantly pointing to the benefits of the changes themselves and the results and rewards that will come, along with the changes, as a result.

Kotter \& Heskett (1992) point out that the main role of management is to initiate motivational activities that support creativity and innovation in the business activities of employees, clients and stakeholders, enabling the organization's managers to improve and promote its success. Work motivations are individual, and it is therefore difficult to find the clear boundary of the motivator, the reason and moment of the creation. For the same reason, there are different definitions of motivation for work.

Wren \& Voich (1994) state that motivation, viewed from the perspective of a manager, could be defined as something that ensures that employees behave in a certain, satisfactory way, which will contribute to achieving the goals of the organization, while at the same time, the needs of employees are satisfied in the best possible way. Motivation, according to these authors, consists of several factors that initiate, organize, lead, guide and stimulate work activities in terms of their duration and intensity. An even simpler definition of motivation was given by Chamy (1996), believing that motivation is the ability of a manager or leader to extract his maximum from the average worker. Greenberg \& Baron (1998) state that literature dealing with the field of organization theory agrees with the basic principles of understanding employee motivation, and it comes down to its definition which emphasizes that "motivation is a set of different processes that direct, initiate, organize and guide the behavior of employees to some specific and pre-determined goal." Since motivation is an abstract category that is not measurable by any measuring units, it can only be someone's subjective assessment based on observing the behavior of workers during the performance of their tasks.

The fact that someone does a good and responsible job does not absolutely guarantee that this person is motivated to work. It is therefore clear that work motivation and performance are by no means complementary or at the same time present with one of the employees, although, of course, they do not exclude each other. There are employees who make minimal efforts in achieving a certain result, while their colleagues can achieve the same results only by investing their maximum efforts. Various employee motivation studies confirm that employees most often have several types of motivation at the same time. Some of them are motivated only by positive motivators such as career progression or organization, self-realization, fulfillment of ambitions and self-actualization, as well as confirmation of their own value. Others, however, can be motivated by the fear of losing work and the inability to feed their families, and the like. Most often, however, there is a combination of positive and negative motivators.

For example, research on cultural traditions and their impact on motivation, carried out by Elizur et al. (1991), produced unexpected results. This international survey was conducted on 2280 employees from eight different countries with completely different customs and traditional values. The countries 
from which the respondents came were: Hungary, Germany, the Netherlands, the United States, Israel, Korea, China and Taiwan. Although eastern hemisphere from countries such as China, Korea, Taiwan and the like have somewhat similar values compared to developed Western countries, this research did not recognize them as distinctive. Namely, in all countries, except in Germany, success at work as the main motivator was in second place, while in Germany it was on an incredible eighth. Highly appreciated is having interesting everyday activities at work, almost in all countries except in Hungary (seventh) and China (eighth place). The amount of income is the highest evaluated motivator in Hungary (fifth), while in China it occupies only 20th place in the ranking of the motivators. Logically, the conclusion is that workers around the globe have a need to do a job that is interesting to them, and to be successful, regardless of the cultural heritage, the value system they come from, the economic situation and social origin. The results of this research indirectly and unequivocally indicate that there are many factors that directly affect the motivation of employees, which are mutually conditioned. Elizur et al. (1991) explain the basic five:

1. Individual traits and characteristics of each individual (interests, values, needs, attitudes, aspirations, motivation achievements, other internal motives),

2. Characteristics of the work performed (type, activity, level of responsibility, degree of autonomy in work, creativity of work, degree of stress, degree of self-control and so on)

3. The characteristics of the working environment and the overall organizational climate, i.e. the environment (organization of work, degree of organization of the company, quality and efficiency of internal and external communication of the organization, mutual relations between management and employees, as well as relations among employees in the organization)

4. Characteristics and level of technological and economic development of the organization itself, as well as its direct environment, that is, the society as a whole, and

5. Characteristics of social organization, geographical area, cultural patterns and value system, religion, economic opportunities and so on.

According to Eliur et al. (1991) The management of the organization is not in a position to control the effect and influence of all the groups of the most significant factors of employee motivation with equal intensity. However, management is in some way obliged to study and get acquainted with all these motivational factors, as well as to manage all motivation factors that fall within the competence of the organization itself. First of all, this refers to the individual characteristics of individuals within the organization, the characteristics of the work itself, and the factor that describes the characteristics of the organizational (working) environment.

Herzberg at al. (1959) formulated the Two Factor Theory, developing and explaining its own, at that time controversial claim that, after satisfying the basic human needs, the money ceases to be motivation for employees. After publishing this theory, the discourse in which the value of the employees themselves is mentioned is the dominant pre-eminence of the organization, influencing the approaches to motivation and management of employee performance. The aforementioned theory, published by Herzberg and associates (1959), made the man as an economic being to return to an organizational position in many contexts, similar to those that prevailed before the publication of the results of their research. This motivation research conducted in the middle of the last century has shown a dual approach to the nature of a human character. The first approach sees people as basically 


\section{Intermationall Qualilty Conference 13}

lazy and uninterested in business and as those who need external stimulation to be motivated. The other approach, however, suggests that the motivation of employees comes from within and is caused by the monetary benefits it will receive, as well as by the social security that only brings employment. Herzberg et al. (1959) state in their research that there is a complex interaction between internal and external factors of motivation and explore the circumstances in which employees as individuals respond and react to certain types of internal and external stimuli. A similar study was carried out by Vroom (1964), where he investigated the influence of internal factors specific to each person on the different behavior of individuals. Undoubtedly for motivation research, Vroom (1964) points out that certain aspects of leadership theory are implicit, but significantly related to external factors that influence motivation.

All people continually react to their own internal impulses, but also to the external environment they are in. Also, our impulses and the external environment are in constant interaction. As a result, we react to what Rotter (1975) describes as psychological situations. Consequently, the behavior of an individual in the organization can be predicted based on our knowledge of the psychological situation. Rotter (1975) introduced the concept of the control locus as a form of the general kind of expectation that an individual has, and suggests that individuals with an expressed internal control locus have high expectations in the sense that the desired corroboration is under their control and that they can affect them. Those individuals who have a pronounced low degree of internal and augmented degree of the external control locus experience themselves, their behaviors, and their support for their behavior, as something that is influenced by higher powers, fate, or simply, in the power of other people. Expectations, goal setting, capital and desired support, according to Rotter (1975), resulted in the development of a simple model of motivation. This model assumed that once the needs of the employees were met and when organizational goals were defined, the next step was the establishment of rewards and attitudes and their connection with certain desired forms of employee behavior, in order to meet the goals of the organization, but also needs of employees. If all the above conditions are met and in line, this will inevitably lead to high work motivation. Likewise, if all conditions do not fit and do not interact properly, high motivation of employees will be missing.

The results of the research carried out by Herzberg et al. (1959) show that selfactualization and approval by executives are increasingly declining. This can be attributed, at least partially, to the fact that organizations with a weaker pyramidal structure offer fewer opportunities for advancement. Nevertheless, it has been found that poor relationships with the superiors play a vital role in discouraging employees to contribute to organizing new ideas and participating in their realization. It can be concluded that the encouragement and approval of some employees can encourage them to contribute to the company with their ideas, their number is significantly lower than those who are motivated by the desire to overcome frustration and contribute to organizational success. In this regard, one of the valuable contributions an organization can create is the development of systems and processes that will enable employees to work together to define problems and overcome frustrations (obstacles) in order to encourage managers to establish this practice for the general well-being of both other parties. Herscovitch \& Meyer (2002), explained the commitment to organizational change in their paper, proposing a three-component model and suggested that it has advantages similar to those found in the literature related to commitment to the organization (for example, the improved ability to predict the 
behavior of employees). Therefore, the affective commitment to change, according to these authors, relates to the desire to support the change. Continuous commitment to change is based on the ability to recognize the costs that are incurred by the change in resistance. On the third hand, the normative commitment to change reflects the sense of obligation to support the changes.

The attitude of the employee toward the organization shapes his interpretation, ie understanding of what organizations are doing and how they act. Pfeffer (1994) points out that the quality of relationships among employees plays an important role in their acceptance of change and active participation in their implementation, and that organizations are increasingly recognizing the value of intra-organizational relationships. As interpersonal relationships between employees affect changes in the organization, the relationships of employees with managers also influence the development of social and all other changes within the organization. The quality of these complex relationships and relationships certainly influences the overall well-being of the organization, makes it healthy or unhealthy environment for work, and has a great impact on all its stakeholders, and especially the clients and users of its services.

Taking into account the aforementioned theories, Heening-Thurau et al. (2002) reveal that there is general consensus regarding the three components of the quality of relationships, which are treated more as interconnected than independent components: satisfaction with the company, commitment to the company and trust in the company. Their research has shown that employees who believe that their managers are supporting and encouraging them, tend to be more committed to their organizations. Therefore, while employees are interdependent in complex relationships, the relationship between employees and managers is vital to the commitment to organizational change. It is a satisfaction according to an employee's assessment, that the organization's relationships are fulfilling and rewarding. Employees who are extremely satisfied with their relationship with the superiors are very likely to develop an affective commitment to changes in organizations and a normative commitment to change. Employee satisfaction is seen by the authors van Dyne \& Pierce (2004) as a driver leading to employee behavior, such as increased work performance, for example. When the aforementioned factors of trust and commitment to the organization of application in practice come to listening to others and acceptability for their ideas, as well as cooperations - employee engagement and dedicated work leading to common goals, and the commitment itself leads employees to give additional energy to their business in order to achieve the goals set. Trust towards the leadership of the organization builds credibility and acceptance of employees who are facing organizational changes. Employees who have quality relationships with colleagues (relationships that carry a high degree of satisfaction, dedication and trust) are more inclined to be extremely committed to the strategies and goals of their organization. Therefore, it can be concluded that the quality of relationships between employees and their managers is a strong predictor of commitment to the organizational changes of the employees themselves.

Motivation is a powerful force that implies certain types of behavior, especially desirable. Coopey \& Hartley (2004) conducted a survey in which they stated that the results led them to believe that motivation also affected the attitudes of employees. Specifically, motivation shows a high correlation with devotion to organizational changes. Namely, these authors state that in the literature there is a growing presence of the position that is in favor of the thesis that there is a high correlation, of a positive sign, between the 


\section{Intermationall Qualilty Conference}

QUA IITY MIISAEAIRCII'

motivation at work and the attitude of the employees towards the changes.

\section{Research methodology}

This research was conducted by the survey in 2018. There were 354 survey questionnaires that were filled in by 137 male and 217 female employees in different sectors in 10 countries in Europe. The research uses factor, discriminative, Multiple regression analysis as well as Pearson correlation statistical methods when analyzing data, and explains the results of statistical analysis. This research focuses on the quality of work life and its correlation to indicators of external communication of an organization. This paper is created with the idea to contribute to a scientific fundus that explains external communication of organization and motivation of employees, comparing it to its influence to Quality of Work Life of employees.

\subsection{Hypothesis}

Based on scope of authors' interests, literature review and empirical research two Hypothesis of this research have been defined - H1: "There is a statistically significant correlation between (un)successful external communication of the organization and motivation of its employees" and H2: "There is statistically significant correlation between the process of intensifying activities related to external communication of the organization with the increase in the motivation of its employees." Both hypotheses have been proved.

\subsection{Sample}

The study conducted in 2018 questioned employed citizens in 10 countries of
Southern and Western Europe. It consisted of 354 participants. The chosen sample was suitable for the purpose of this research paper; respondents were randomly selected by online surveys, field work - by personal contacts with employees in certain companies etc. This research was predominantly based on work motivation and its correlation to Quality of work life, but then the authors made correlation to indicators of external communication on order to discover whether there is correlation to it, which is a completely new scientific information.

\subsection{Instrument of research}

The instruments used was a semi-stratified questionnaire. The questionnaire was conducted from September to December 2018. Along with socio-demographic characteristics, it contains thematically divided parts: the first refers to respondents' judgement on their Quality of Life and their working life in particular, then, there is a part which questions their views on the organization they work for and their job motivation, and finally, there is a part which questions external communication of their organization and its universal indicators.

\subsection{Data Analysis}

The questionnaire was then used as part of data that was statistically described and calculated in SPSS program. Factor analysis was done (Promax rotation), discriminant analysis, descriptive statistical methods, Multiple regression analysis as well as Pearson's correlation coefficient and results gained can therefore be considered valid. The statistical methods used as well as techniques of interpretation were chosen in accordance with regard to specifics of this particular research, as well as hypotheses set. 
According to the goals and Hypotheses of the research we conducted in 2018, the attitudes of the respondents concerning the quality of work life, their work motivation and external communication of their organization were examined. Respondents expressed their assessment of the state their companies and motivation as well as the quality of external communication on the continuum from 1 to 5 , and their mutual correlations are shown in the tables, under the section "Results" of this paper.

\subsection{External communication in an organization and its 6 indicators (factor analysis)}

In line with the $\mathrm{H} 1$ hypothesis, the views of the respondents about the quality of external communication in the company in which they are employed are tested. This questionnaire has 25 claims, aligned on a Likert scale, and respondents expressed their assessment on a continuum of 1 to 5 . The questionnaire consists of following claims: The organization I work in employs a Communication Manager, The organization's communication to the outside (public) is thoroughly prepared and conceived, never random or uncontrolled, Communication in the organization takes place under controlled conditions, hierarchically and strictly, I can turn to the superiors at any moment, Relations among employees are healthy and supportive, The organization I work at has great communication with clients, The clients of the company are loyal and they always come back to us, The company's "outward" (external) communication is constantly contributing to the success of the organization itself, The company I work for invests in marketing heavily, The company I work for is very present in the online world,
The brand / brands of the organization I work for are very recognizable in my country and beyond, I am proud to be part of this organization, My friends find me very lucky for working in this company, The money invested in marketing is multiplied in return, Due to good marketing, we are constantly getting new clients, The success of the organization I work for is something I perceive as a personal success, I feel good that, when I say the name of the company I work for, everyone knows what I am talking about, The company I work for often supports humanitarian organizations and events they organize, The company in which I work is a socially responsible company, Because of the company I work for, the world is a better place, The company I work for is extremely successful and this is clear to the entire public, The attitudes with which the company presents itself publicly are the standpoints of the employees in it, The success and public recognition of the company I work for is motivating me for more dedicated work in it, The importance and weight of the company's name is equally strong motivation as my salary is, The attitudes with which the company presents itself publicly are the same ones that are applied within the organization.

In accordance with the research hypotheses, analysis of the main components in the measurement area of the questionnaire for assessment of the quality of external communication was made with the aim of establishing the basic indicators of external communication. According to the Characteristic root criterion above 1 , it was possible to isolate up to 6 factors, similarly recommended by the Scree test, so we decided to extract all 6 factors rotated by Promax rotation and together explain about $66 \%$ of variance. The obtained scores on these factors were used in further analysis (Table 1, Figure 1). 


\section{Intermationall Qualilty Conference}

Table 1. Analysis of the main components of external communication

\begin{tabular}{|c|c|c|c|c|}
\hline \multirow{2}{*}{$\begin{array}{l}\text { Main } \\
\text { components }\end{array}$} & \multicolumn{3}{|l|}{ Before rotation } & \multirow{2}{*}{$\begin{array}{l}\text { After rotation } \\
\text { Characteristic root }\end{array}$} \\
\hline & Characteristic root & $\begin{array}{l}\text { Percentage } \\
\text { variance }\end{array}$ & Cumulative $\%$ & \\
\hline I & 9.073 & 36.292 & 36.292 & 6.258 \\
\hline II & 2.275 & 9.099 & 45.391 & 6.194 \\
\hline III & 1.697 & 6.789 & 52.180 & 6.005 \\
\hline IV & 1.337 & 5.347 & 57.527 & 4.566 \\
\hline $\mathrm{V}$ & 1.095 & 4.379 & 61.906 & 4.608 \\
\hline VI & 1.034 & 4.138 & 66.044 & 3.009 \\
\hline
\end{tabular}

Figure 1. External communication factor analysis scree plot

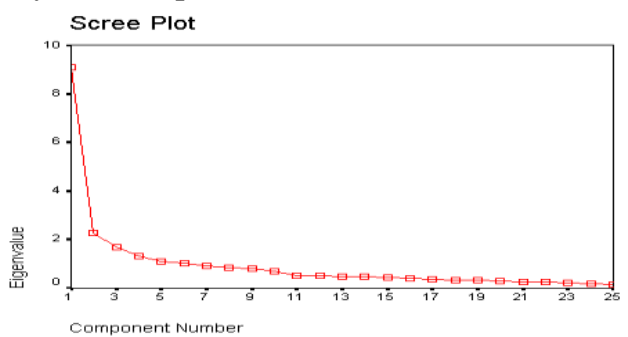

The matrix structure of first factor explained $36 \%$ of variance and is called: Good communication with clients.

Other factors were named: Corporate identity, Corporate social responsibility, Branding, Good marketing, and Wellstructured communication.

\subsection{Attitudes of employees on the work motivation}

Work motivation and employee satisfaction was checked by a questionnaire of 30 claims, to which the respondents responded to the extent to which they relate. The questionnaire consists of following claims: My job is very boring, I hate my job, I really love my job, If I won a lottery, I would abandon this job, I like to avoid obligations while I'm at work, The best part of a working day is a break for coffee, lunch and other breaks, I work hard and I try my best to do my job the best I can, I enjoy thinking about my workplace while I'm at work, I do not like to think about my workplace while I'm at work, The work I do is important to me personally, My job is to serve me purely so that I can earn a living, I like to think about new responsibilities in my workplace, The job for me is not just the way money is earned, but it has a higher value, I like to think about ways I can improve my performance at work, The best part of the day is when I leave my job, I get personal satisfaction from the work I do, The company I work with provides me with all the necessary resources and tools for doing my job, I spend my day planning what I'm going to do when I retire, I'm thinking about finding a new job, I consider my work interesting, I do not have enough desire to do my job, The company I work for does not support me in doing my job, The company in which I work, makes it easier to do my job with its actions, I believe that my position is secured, Bonuses and benefits in the company are fairly shared, I get constant support for improving my career from my employer, I am very pleased with the company's communication, The company prevailingly has good communion and team spirit, I feel that my job is a realization of my professional tendencies and interests, I have a plan in which direction my career will go.

On the questionnaire of work motivation, the respondents mostly agree with the following statements: I work hard and try very hard to do my job the best I can (AS = 4.32), I like to think about ways to improve my performance at work (AS = 3.94), The job 
for me is not just the way money is earned, but it has a higher value (AS = 3.72). On average, the respondents the least agree with the claims: I hate my job (AS = 1.71), I spend my day planning what to do when I retire (AS $=1.71)$, I like to avoid obligations while $\mathrm{I}$ am at work (AS $=1.73$ ).

In accordance with the set goals of this research, analysis of the main components in the measurement area of the questionnaire for work motivation was made. The obtained results showed that, according to
Characteristic Root criterion above 1, we can isolate up to 6 factors, while according to the Scree test, it is recommended to isolate 2 components. We decided on the two most interoperable factors, which were rotated by the Promax rotation and together explain about $42 \%$ of the variance. In this way, the questionnaire measurement area has been reduced to two key factors: High motivation for work and Low motivation for work. The obtained scores on these factors were used in further analysis (Table 2, Figure 2).

Table 2. Analysis of the main components of work motivation

\begin{tabular}{|l|l|l|l|l|}
\hline $\begin{array}{l}\text { Main } \\
\text { components }\end{array}$ & \multicolumn{2}{|l|}{ Before rotation } & After rotation \\
\hline & Characteristic root & $\begin{array}{l}\text { Percentage of } \\
\text { variance }\end{array}$ & Cumulative \% & Characteristic root \\
\hline I & 10.263 & 34.210 & 34.210 & 9.403 \\
\hline II & 2.433 & 8.111 & 42.321 & 7.744 \\
\hline
\end{tabular}

Figure 2. Scree plot

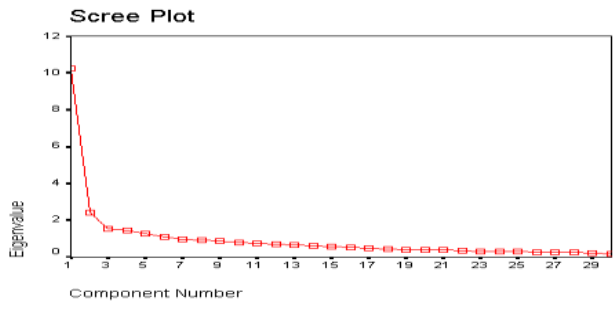

The first isolated factor includes the largest percentage of variance, about $34 \%$. Given the total percentage of variances explained by two factors, this saturation can be considered quite high. The positive pole of the factor is well defined by the claims that talk about job satisfaction and high work motivation and work satisfaction. With the factor in the positive direction the most important correlation is with the following statements: I really love my job; The job I do is important to me, personally; The job for me is not only the way money is earned, it also has some higher value; I like to think about ways how can I improve my performance at work; I get personal satisfaction from the work I do, I consider my work interesting, I perceive my job as a realization of my professional tendencies and interests, and so on. The negative pole factor is also well defined by the following statements: I do not have enough desire to do my job, I hate my job, My job is very boring, The most beautiful part of the day is when I leave my job. My job serves me purely to have what I am to live and the like. People who achieve high scores on this factor are very motivated to work, they love their work, have personal satisfaction from work, they do business with lots of energy and energy. Based on this factor, it is called High motivation for work.

The second factor gathers claims that, according to their content, indicate job dissatisfaction and low motivation for work. The factor is predominantly defined by claims that are in a negative correlation with it, such as: I really love my job, I perceive my job as a realization of my professional preferences and interests, The company predominates community and team spirit, I am very satisfied with the communication in the company, The Employer provides me constant support for improving my career, bonuses and benefits in the company are just 
shared, I get personal satisfaction from the work I do, I consider my work interesting. The positive pole of the factor is defined by the following statements: If I won at the lottery, I would have left this job, I do not have enough desire to do my job, The most beautiful part of the day is when I leave my job, I'm thinking of finding a new job; My job serves me very clearly as a source of living. People who have high scores on this factor are dissatisfied with their work and working conditions, as well as interpersonal relationships, are not motivated to work, and are looking for another job. This factor is called Low motivation for work.

\subsection{Correlation of external communication and work motivation of employees}

In accordance with the set hypothesis of the research - correlation between external communication and motivation of the employees, a Pearson correlation analysis between two motivation factors and six indicators of external communication factors has been made. First, Person's correlation coefficients were made in order to verify $\mathrm{H} 1$ hypothesis, and then Multiple regression analysis to test $\mathrm{H} 2$ hypothesis.

1) Pearson coefficients of correlation between motivation factors and external communication factors

Table 3. Pearson's coefficient of correlation

\begin{tabular}{|c|c|c|c|}
\hline & & $\begin{array}{l}\text { High level of work } \\
\text { motivation }\end{array}$ & $\begin{array}{l}\text { Low level of work } \\
\text { motivation }\end{array}$ \\
\hline \multirow[t]{2}{*}{ Good communication with clients } & $\mathrm{R}$ & $.492(* *)$ & $-.689(* *)$ \\
\hline & $\mathrm{P}$ & .000 & .000 \\
\hline \multirow[t]{2}{*}{ Corporate identity } & $\mathrm{R}$ & $.565(* *)$ & $-.538(* *)$ \\
\hline & $\mathrm{P}$ & .000 & .000 \\
\hline \multirow[t]{2}{*}{ Corporate social responsibility } & $\mathrm{R}$ & $.366(* *)$ & $-.386(* *)$ \\
\hline & $\mathrm{P}$ & .000 & .000 \\
\hline \multirow[t]{2}{*}{ Branding } & $\mathrm{R}$ & .084 & $-.238(*)$ \\
\hline & $\mathrm{P}$ & .143 & .016 \\
\hline \multirow[t]{2}{*}{ Good marketing } & $\mathrm{R}$ & $.308(* *)$ & $-.349(* *)$ \\
\hline & $\mathrm{P}$ & .000 & .000 \\
\hline \multirow[t]{2}{*}{ Well-structured communication } & $\mathrm{R}$ & $.330(*)$ & $-.223(* *)$ \\
\hline & $\mathrm{P}$ & .014 & .000 \\
\hline \multicolumn{4}{|c|}{$\begin{array}{l}\text { r-Pearson linear correlation coefficient } \\
\text { p-level of significance: } * * \\
\text { Correlations are significant at } 0.01 \text { leve }\end{array}$} \\
\hline
\end{tabular}

The factor that speaks of high motivation for work statistically significantly correlates with all factors of external communication, except with Branding. All coefficients are of moderate to medium intensity, and positive sign, and the strongest correlation is with the factor named Corporate identity. This result means that the better communication with the clients and within the company, the more employees identify with the company, and the greater the social responsibility of the company and its marketing, the more employees are more motivated to work. The factor related to low work motivation statistically correlates with all indicators of external communication, all correlations are negative, which means that the lower quality of the factors mentioned in the external communication is lower, the lower is the work motivation of the employees.

On the basis of the obtained results, we can say that the hypothesis $\mathrm{H} 1$ of this research which reads: There is a statistically significant connection between the (non) 
QUA II II Y Y

DIISIFAIRQI

successful external communication of the communication factors organization with the motivation of its employees, confirmed.

2) A multiple regression analysis in which the criterion variable is a work motivation

Table 4: Coefficient multiple correlation

\begin{tabular}{|l|l|l|l|l|}
\hline Model & $\mathrm{R}$ & $\mathrm{R}^{\mathbf{2}}$ & $\begin{array}{l}\text { Corrected } \\
\mathrm{R}^{2}\end{array}$ & $\begin{array}{l}\text { Std. } \\
\text { mistake }\end{array}$ \\
\hline 1 & .634 & .402 & .390 & .785 \\
\hline
\end{tabular}
and a set of predictors are external

Table 5: Assessment of the significance of the regression model

\begin{tabular}{|l|l|l|l|l|l|l|}
\hline Model & & $\begin{array}{l}\text { Sum of the } \\
\text { squares }\end{array}$ & $\begin{array}{l}\text { Number of degree } \\
\text { of freedom }\end{array}$ & Average square & F & P \\
\hline 1 & Regression & 123.374 & 6 & 20.562 & 33.358 & .000 \\
\hline & Residual & 183.693 & 298 & .616 & & \\
\hline & Total & 307.067 & 304 & & & \\
\hline
\end{tabular}

The regression model is statistically significant at $\mathrm{p}=0.000$.

The multi-correlation coefficient is $\mathrm{R}=$ 0.634 , and the set of predictors explains about $40 \%$ of the variability of the variable system.

Based on these results we can say that there is a higher level of correlation between the criteria and the predictor set of variables.

Table 6: Partial contribution of predictors

\begin{tabular}{|l|l|l|l|}
\hline & Beta & $\mathrm{T}$ & $\mathrm{P}$ \\
\hline (Constant) & & -.221 & .825 \\
\hline $\begin{array}{l}\text { Good communication } \\
\text { with clients }\end{array}$ & .296 & 5.439 & .000 \\
\hline Corporate identity & .428 & 7.324 & .000 \\
\hline $\begin{array}{l}\text { Corporate social } \\
\text { responsibility }\end{array}$ & .031 & .517 & .606 \\
\hline Branding & .147 & 2.843 & .005 \\
\hline Good marketing & .063 & 1.167 & .244 \\
\hline $\begin{array}{l}\text { Well-structured } \\
\text { communication }\end{array}$ & -.033 & -.663 & .508 \\
\hline
\end{tabular}

Statistically significant beta coefficient is visible within following factors: Good communication with clients (the coefficient of positive sign and lower intensity is 0.296), Corporate identity (coefficient of moderate intensity 0.296) and Branding (coefficient of low intensity is 0.147 ) (Table 6). On the basis of the obtained partial contributions of the predictors, we can conclude that by increasing the activities related to external communication, especially by identifying the employees with the success of their company, as well as by communicating with clients and branding, the motivation of employees is increased, so that the hypothesis $\mathrm{H} 2$ of this research, which reads as follows: There is statistically significant correlation between the process of intensifying activities related to external communication of the organization with the increase in the motivation of its employees, is confirmed.

\section{Discussion}

Motivation and work behavior of employees is understood as a very complex psychological process that is very individual and comes as "inside", self-motivation of individuals, and external influence. In considering this phenomenon, it has to be taken into account that different groups of employees are in similar positions, share similar responsibility, but also motivators, and need to adapt to them in order to successfully implement the organizational changes. In given situations, various approaches to employee motivation by the manager to change give different results, and special attention must be paid to these approaches. If the change is unsuccessful and poorly implemented, or simply the individual characteristics of employees or certain groups of employees are not taken into account, in order to motivate them 


\section{International Cuality Conference 1}

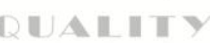
IRIFSIFAIRCIH

enough to participate actively in the process of implementation of changes, this will inevitably lead to poor relations in the organization. The findings show that there is both positive and negative correlation between (un)successful external communication of the organization and motivation of its employees that describe Quality of work life of employees. The findings indicate that, among other things, better communication with customers as well as within the company itself, along with increased corporate identification of the employees, makes the employees more motivated to work. Findings also show that personal happiness and satisfaction are prominent factors of the Quality of work life. The hypothesis H1 of this research, which reads as follows: "There is a statistically significant correlation between (un)successful external communication of the organization and motivation of its employees" has been proved. The hypothesis $\mathrm{H} 2$ od this research, which reads as follows: "There is statistically significant correlation between the process of intensifying activities related to external communication of the organization with the increase in the motivation of its employees" have both been proved.

\section{References:}

Chamy, C. (1996). Effikasan menadžer. Beograd: Grmeč.

Elizur, D., Borg, I., Hunt, R., \& Beck, I. M. (1991). The structure of work values: A cross cultural comparison. Journal of Organizational Behavior, 12(1), 21-38.

ellah Mejbel, A. A., Almsafir, M. K., Siron, R., \& Mheidi, A. S. (2013). The drivers of Quality of Working Life (QWL): A critical review. Australian journal of basic and applied sciences, 7(10), 398-405.

Grinberg, Dž., \& Baron, R. A. (1998). Ponašanje u organizacijama, razumevanje i upravljanje ljudskom stranom rada. Beograd: Želnid.

Harrington, B., \& Hall, D. T. (2007). Career management \& work-life integration: using selfassessment to navigate contemporary careers. Sage.

Henning-Thurau, T., Gwinner, K. P., \& Gremler, D. D. (2002). Understanding relationship marketing outcomes: an integration of relational beliefs and relationship quality. Journal of Service Research, 4, 3, pp. 230-248.

Herscovitch, L. \& Meyer, J. P. (2002). Commitment to organizational change: extension of a three-component model. Journal of Applied Psychology, 87, 3, pp. 474-487.

Herzberg, F., Mausner, B., \& Snyderman, B. (1959). The Motivation to Work. New York, NY: Wiley.

Heskett, J. L., \& Kotter, J. P. (1992). Corporate culture and performance. Business Review. Vol, 2(5), 83-93.

Hosseini, S. M., Jorjafki, G. M., \& Ashrafi, A. M. (2010, July). Notice of Retraction Quality of work life (QWL) and its relationship with performance. In 2010 IEEE International Conference on Advanced Management Science (ICAMS 2010) (Vol. 1, pp. 559-562). IEEE.

Lau, T. Wong, Y. H., Chan, K. F., \& Law, M. (2001). Information technology and the work environment - does IT change the way people interact at work? Human systems management, 20(3), 267-279.

Mohan, G. K., \& Kanta, K. N. M. (2013). Quality of work life: An application of factor analysis. SUMEDHA Journal of Management, 2(3), 4.

Pfeffer, J. (1994). Competitive Advantage through People: Unleashing the Power of the Workforce. Boston, MA: Harvard Business School Press. 
QUA IIII Y

Robert, S. A., Cherepanov, D. Palta, M., Dunham, N. C., Feeny, D. \& Fryback, D. G. (2009).

Robert, S. A., Cherepanov, D., Palta, M., Dunham, N. C., Feeny, D. \& Fryback, D. G. (2009). Socioeconomic status and age variations in health-related Quality of Life: Results from the national health measurement study. The Journal of Gerentology, 64B (3), 378-389.

Rotter, J. B. (1975). Some problems and misconceptions related to the construct of internal versus external control of reinforcement. Journal of Consulting and Clinical Psychology, 43, 1, pp. 56-57.

Sahni, J. (2017). Exploring what constitutes 'quality' in quality of work life for female employees. International Journal for Quality Research 11 (4), 785-798

Schuessler, K. F., \& Fisher, G. A. (1985). Quality of life research and sociology. Annual Review of Sociology, 11, 129-149.

Sharma, N., \& Verma, D. S. (2013). Importance of Quality of Work Life in Small Scale industries for employees. International Journal of Latest Research in Science and Technology, 2(2), 153-156.

Sinha, C. (2012). Factors affecting quality of work life: Empirical evidence from Indian organizations. Australian Journal of Business and Management Research, 1(11), 31-40.

Swamy, D. R., Nanjundeswaraswamy, T. S., \& Rashmi, S. (2015). Quality of work life: scale development and validation. International Journal of Caring Sciences, 8(2), 281.

The WHOQOL Group (1998). The World Health Organization Quality of Life assessment (WHOQOL): Development and general psychometric properties. Social Science and Medicine, 46, (12), 1569-1585. doi: 10.1016/s0277-9536(98)00009-4

van Dyne, L., \& Pierce, J. L. (2004). Psychological ownership and feelings of possession: three field studies predicting employee attitudes and organization citizenship behaviour. Journal of Organizational Behaviour, 25, pp. 439-459.

Vroom, V. H. (1964). Work and motivation. New York, NY: Wiley.

Wren, A. D., \& Voich Jr, D. (1994). Menadžment, Beograd. Republika Srbija, 331.

Tanja Radošević

Faculty of Media and

Communications,

Belgrade,

Serbia

tanja.radosevic@fmk.edu.rs

\section{Marija Runić Ristić}

Faculty of Management, Sremski Karlovci,

Serbia

runic@famns.edu.rs 